\title{
DETERMINANTS OF ADHERENCE TO ANTIRETROVIRAL DRUGS AMONG PEOPLE LIVING WITH HIV/AIDS IN THE IFE-IJESA ZONE OF OSUN STATE, NigerIA
}

\section{Authors:}

Muhammed O. Afolabi

Kayode T. Ijadunola ${ }^{2}$

Adesegun O. Fatusi ${ }^{2}$

Olayinka A. Olasode

\section{Affiliations:}

${ }^{1}$ Department of Family

Medicine, Ladoke Akintola

University Teaching

Hospital, Nigeria

${ }^{2}$ Department of

Community Health

Obafemi Awolowo

University, Nigeria

${ }^{3}$ Department of

Dermatology and

Venereology, Obafemi

Awolowo University,

Nigeria

Correspondence to:

Muhammed O. Afolabi

e-mail:

afolabimo@gmail.com

Postal address:

Department of Family

Medicine, Ladoke Akintola

University Teaching

Hospital, PMB 5000,

Osogbo 230001, Nigeria

\section{Keywords:}

Factors; adherence;

PLWHA; antiretroviral

drugs; Nigeria

Dates:

Received: 17 Nov. 2008

Accepted: 07 Mar. 2009

Published: 15 Apr. 2009

How to cite this article: Afolabi MO, Ijadunola KT, Fatusi AO \& Olasode OA.

Determinants of adherence to antiretroviral drugs among people living with HIV/AIDS in the Ife-Ijesa zone of Osun state, Nigeria. Afr J Prm Health Care Fam Med. 2009;1(1), Art. \#6, 6 pages. DOI: $10.4102 /$ phcfm. v1i1.6

This article is available at: http://www.phcfm.org

(C) 2009. The Authors. Licensee: OpenJournals Publishing. This work is licensed under the Creative Commons Attribution License.

\section{ABSTRACT}

Background: The advent of antiretroviral (ARV) drugs has transformed HIV/AIDS into a chronic manageable disease and strict adherence is required for the medication to be effective. However, factors influencing adherence to ARV therapy (ART) vary from country to country.

Method: 120 subjects who received ARV drugs at a federal government-designated ART site located within the Obafemi Awolowo University Teaching Hospital complex, (OAUTHC), Ile-Ife, and a community-based non-governmental organisation, Living Hope Care (LIHOC), Ilesa, from February to May 2006 were serially recruited and studied. Relevant data were collected using an interviewer-administered, patient medication adherence questionnaire. Focus group discussions were also held among the subjects to further elicit qualitative information on factors influencing adherence to ART.

Results: The age of participants ranged from 21 to 65 years with a mean age of $40.2+10.3$ years Participants had been on ARV drugs for a period ranging between three and 60 months. The overall adherence rate in the study population was $44 \% .66 \%$ of participants who accessed ARV drugs from LIHOC, Ilesa, had good adherence while only $14 \%$ of participants who accessed ARV drugs from OAUTHC, Ile-Ife, had good adherence. Participants with good adherence did not pay funds for the preliminary ARV eligibility investigations and they were also offered regular adherence counselling. These facilities were barely available in the group with poor adherence. Demographic factors such as age, gender and marital status did not seem to have any significant association with adherence level $(\mathrm{p}>0.05)$.

Conclusion: The level of adherence was high in a cohort of PLWHA accessing ARV drugs in Ilesa while it was low among PLWHA receiving ART in Ife. The most important reasons for this difference were lack of funds for investigations and poor psycho-social counselling.

\section{INTRODUCTION}

The development of antiretroviral (ARV) drugs has transformed HIV/AIDS to that of a chronic manageable disease. Studies have reported improved quality of life of PLWHA on ARV therapy (ART), reduced progression of the disease and declining mortality from the pandemic., ${ }^{1,2}$ However, strict adherence is required to achieve therapeutic success in HIV management. Paterson et al. suggest that near-perfect adherence, that is, higher than $95 \%$, is necessary to achieve suppression of HIV replication (HIV-RNA $<400$ copies $/ \mathrm{ml})^{3}{ }^{3}$ Other data, however, suggest that adherence levels of $100 \%$ achieve even greater benefits. ${ }^{4,5}$ Inadequate viral suppression resulting from failure to adhere closely to treatment causes a worsening of immunological and clinical states, which may eventually lead to emergence of drug-resistant HIV strains. ${ }^{6}$

The consequences of low adherence are serious for the individual, public health and the optimal use of limited health care resources. ${ }^{6}$ Non-adherence in patients on anti-HIV therapy is the strongest predictor of failure to achieve viral suppression below the level of detection. ${ }^{7}$ Conscientious treatment adherence is difficult under any circumstances, considering the unforgiving nature of HIV replication, the complexity of the highly active antiretroviral therapy (HAART) regimens, and associated short- and long-term toxicity. Adherence to HAART becomes a central issue of concern, not only because factors that influence a patient's ability to adhere are multiple and complex, but also because treatment resistance can occur for an entire class of ARV drugs and ultimately renders HAART ineffective. In addition, resistant viral strain of HIV can be transmitted to newly infected individuals who will therefore have fewer effective treatment options from the start of their HIV infections.

Studies have reported determinants of adherence to ARV medication. ${ }^{8-20}$ While socio-demographic characteristics were reported not to be associated with adherence in some studies, ${ }^{8,9}$ factors such as younger age,,$^{10,11}$ African descent, ${ }^{12,13}$ low income ${ }^{14}$ low levels of education ${ }^{15}$ and psychological factors such as depression, ${ }^{16}$ high levels of stress, ${ }^{9}$ psychiatric conditions ${ }^{3}$ excessive drinking, ${ }^{17}$ and drug use ${ }^{18}$ were associated with adherence. Some studies also suggest that non-adherence tends to increase with the number of times medications are taken per day ${ }^{19}$ and the number of different medications. ${ }^{13}$ Furthermore, patients who are experiencing adverse effects are less likely to adhere than patients who are tolerating the medication. ${ }^{20}$

There is a dearth of data on factors influencing adherence to ART in Nigeria, and this study therefore aims to address this gap.

\section{METHOD}

\section{Study location}

The study was conducted in Ile-Ife and Ilesa, two adjoining towns in Osun State in south-west Nigeria. The two towns form the nucleus of the Ife-Ijesa geo-political zone and house the two units of the Obafemi Awolowo University Teaching Hospital, Ile-Ife, which is one of the ART centres approved by the federal government of Nigeria. Although the HIV prevalence of Osun State was 
estimated at $1.2 \%$, the state was considered a 'hotspot' for HIV transmission in view of numerous junction towns that serve as transit centres for long-distance drivers and travellers to other major cities in Nigeria. ${ }^{22}$ ARV drugs are available free of charge from the federal government, but beneficiaries are expected to undergo mandatory laboratory investigations before commencement of the medication. These investigations cost about 13,000 naira (about \$US104), and are repeated every three months to monitor progress of the patients on the ARV drugs.

LIHOC is a non-governmental, community-based organisation that provides comprehensive care and support for PLWHA The organisation is situated in Ilesa and collaborates with one of the US President's Emergency Plan for AIDS Relief (PEPFAR) sites located within the Nigerian Institute of Medical Research Lagos. Clients from LIHOC access ARV drugs from the PEPFAR facility in Lagos. The laboratory investigations as well as ARV drugs are provided free for all clients, including those from LIHOC, Ilesa. PLWHA are trained in adherence counselling and home-based care. They are also organised into support groups that meet every fortnight to share experiences and discuss issues that affect them. However, at the ART site in Ile-Ife, adherence and psycho-social support were barely existent at the time of the study. The investigator attended a number of such meetings in Ile-Ife and Ilesa.

\section{Study design}

The study employed a cross-sectional, descriptive design.

\section{Study population}

These were patients who tested positive for HIV and were receiving ART in the two recognised ART centres located in the Ife-Ijesa zone of Osun State. These patients had undergone rapid screening tests using HIV $1 / 2$ STAT-PAK and confirmatory tests were done using the Western blot method. The patients underwent further investigations to rule out opportunistic infections such as pulmonary tuberculosis. In the absence of this infection, a CD4 count of $\leq 200 \mu \mathrm{l} / \mathrm{ml}$ is used as cut-off value for commencement of ART. At the time of study, very few HIV-positive people were accessing ARV drugs at the centres.

\section{Sampling technique}

Participants were serially recruited over the study period. All PLWHA on ART were eligible to participate, except those that satisfied the exclusion criteria. These criteria included PLWHA who were acutely ill or those that refused to grant consent for the study. Out of 75 clients approached in the Ilesa site, 70 agreed to participate in the study, while 50 clients consented in the Ile-Ife site out of 53 approached. There was no significant difference in age, sex and other socio-demographic factors between those selected and the rest of the clients at the two sites.

\section{Data-collection instruments}

Data were collected using quantitative and qualitative techniques. The quantitative instrument consisted of a semi-structured, interviewer-administered questionnaire that contains sections on socio-demographic data and factors influencing adherence to ART. Adherence to ART in the previous seven days of the interview was measured by self-report. Initially, the percentage of adherence was calculated for each drug by dividing the number of pills taken by the number of pills prescribed. Then, the percentage of adherence to the antiretroviral ART was estimated by the average of adherence to the drugs. A score of $95 \%$ and above represented good adherence and less than $95 \%$ was rated as poor adherence. ${ }^{3}$

To ensure further exploration of factors influencing adherence to ART among PLWHA, two focus group discussion sessions were held each in Ile-Ife (male and female groups) and Ilesa (male and female groups) using a focus group discussion guide. Participants were segregated by sex to ensure homogeneity and open discussion among same-sex clients. Six to eight clients who had not answered the questionnaires were included in each focus group discussion. A total of 28 clients were randomly selected from the register and 24 people agreed to participate. The focus group discussion sessions were audio-taped and later transcribed. The investigator served as the facilitator for the focus group discussions.

\section{Data analysis}

Quantitative data were analysed using SPSS for Windows, Version 11. Descriptive and inferential statistical tests were employed. These included bivariate (chi-square) and multivariate (logistic regression) analyses to determine correlates or predictors of adherence to ART. The independent predictors of adherence were assessed using a sequence of multivariate logistic regression models. A model was set up with adjustments for socio-demographic and ART variables. Variables selected for inclusion in the subsequent model were based on their significance (that is $\mathrm{p}<0.05$ ) in bivariate analyses or in the prior model.

Qualitative data gathered from focus group discussions were analysed through detailed content analysis and ethnographic summary. This involved verbatim quoting of participants to buttress certain arguments raised in the course of discussion.

\section{Ethical clearance and consent}

Ethical clearance was obtained from the Research and Ethical Committee of OAUTHC, Ile-Ife. Informed written consent was obtained from each participant before the interview.

\section{RESULTS}

One hundred and twenty (120) PLWHA receiving ART at OAUTHC, Ile-Ife, and LIHOC, Ilesa, were studied. 50 subjects $(41.7 \%)$ were recruited from OAUTHC, Ile-Ife, while 70 subjects $(58.3 \%)$ were recruited from LIHOC, Ilesa. The ages of the participants ranged from 21 to 65 years; the mean age was $40.2 \pm 10.3$ years. Participants had been on ART for a period ranging between three and 60 months and the mean period of commencement of ART was $16.9 \pm 12.3$ months.

Table 1 shows that the majority of the clients from the two sites were female, about half were currently married, and that a higher proportion $(64.3 \%)$ of participants attended support group meetings regularly in Ilesa than those in Ile-Ife.

TABLE 1

Socio-demographic distribution of participants

\begin{tabular}{|c|c|c|}
\hline CHARACTERISTICS & ILE-IFE $\quad(n=50)$ & ILESA $(n=70)$ \\
\hline $\begin{array}{l}\text { AGE GROUP (YEARS) } \\
15-24 \\
25-34 \\
35-44 \\
\geq 45\end{array}$ & $\begin{array}{r}0(0.0) \\
9(18.0) \\
19(38.0) \\
22(44.0)\end{array}$ & $\begin{array}{r}5(7.1) \\
22(31.4) \\
30(42.9) \\
13(18.6)\end{array}$ \\
\hline $\begin{array}{l}\text { SEX } \\
\text { Female } \\
\text { Male }\end{array}$ & $\begin{array}{l}31(62.0) \\
19(38.0)\end{array}$ & $\begin{array}{l}48(68.6) \\
22(31.4)\end{array}$ \\
\hline $\begin{array}{l}\text { MARITAL STATUS } \\
\text { Single } \\
\text { Married } \\
\text { Separated } \\
\text { Divorced } \\
\text { Widowed }\end{array}$ & $\begin{array}{r}0(0.0) \\
28(56.0) \\
0(0.0) \\
2(4.0) \\
19(38.0)\end{array}$ & $\begin{array}{r}14(20.0) \\
35(50.0) \\
3(4.3) \\
2(2.9) \\
16(22.9)\end{array}$ \\
\hline $\begin{array}{l}\text { LEVEL OF EDUCATION } \\
\text { No formal education } \\
\text { Primary } \\
\text { Secondary } \\
\text { Tertiary }\end{array}$ & $\begin{array}{l}24(48.0) \\
11(22.0) \\
10(20.0) \\
15(30.0)\end{array}$ & $\begin{array}{l}21(30.0) \\
12(17.1) \\
23(32.9) \\
14(20.0)\end{array}$ \\
\hline $\begin{array}{l}\text { RELIGION } \\
\text { Christianity } \\
\text { Islam }\end{array}$ & $\begin{array}{r}44(88.0) \\
6(12.0)\end{array}$ & $\begin{array}{l}55(78.6) \\
15(21.4)\end{array}$ \\
\hline $\begin{array}{l}\text { SUPPORT GROUP } \\
\text { ATTENDANCE } \\
\text { Regularly } \\
\text { Not regularly }\end{array}$ & $\begin{array}{l}20(40.0) \\
30(60.0)\end{array}$ & $\begin{array}{l}45(64.3) \\
25(35.7)\end{array}$ \\
\hline
\end{tabular}


Figure 1 shows that $14 \%$ of subjects that accessed ARV drugs from Ile-Ife had good adherence compared to $66 \%$ of those that accessed care from Ilesa.

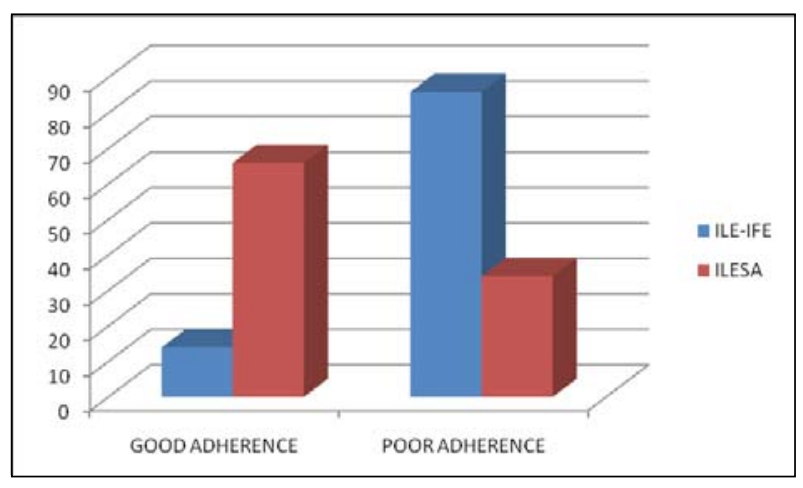

FIGURE 1

Bar chart showing level of ART adherence among study participants

Table 2 shows that participants with formal education were significantly more likely to adhere to ART $(63 \%)$ than were those with no formal education $(37 \%),(\mathrm{p}<0.0001)$. Similarly, other significant correlates of adherence included total monthly income of participants, their affordability of the cost of ARV drugs, their sources of ARV drugs and their membership/attendance at support groups $(\mathrm{p}<0.01)$. Further correlates included the occupational status of the participants and their perceptions of ARV dosage regimens $(\mathrm{p}<0.01)$.

Table 3 shows that the true predictors of adherence to ART among PLWHA in the Ife-Ijesa zone were sources of ART, educational attainment and total monthly income. Participants who attended and got their ARV drugs from LIHOC, Ilesa, were more likely to adhere to ART than were those who attended OAUTHC, Ile-Ife. Similarly, participants who earned a total monthly income of N5 000 (about US\$40) or more and those who had formal education were more likely to adhere than were those who earned less than N5 000 and those without formal education.

\section{RESULTS}

A majority of the focus group discussion participants reported having missed a dose of ARV drugs. This implies that ART was not strictly adhered to. A lady from Ile-Ife remarked as follows:

'Although taking ARV drugs has become part of our life, we still at times forget to take it due to some reasons. I have missed my drugs sometimes. It is one of those things. One cannot be 100\% compliant.'

A male participant from Ilesa submitted that:

'One cannot avoid missing a dose at times. As long as the drug is available, one will take it as soon as one remembers.'

There was, however, no report of outright discontinuation of the treatment regimen among the PLWHA that participated in this study.

Adherence to ART demands certain food requirements. Some of the participants disclosed that they were not economically buoyant to meet these food requirements. A lady from Ilesa submitted the following:

'Most of the time, most of us eat what is available and affordable, not necessarily what is required. To claim that we are meeting the food requirements is an understatement. Even, those without HIV are also not finding this bad economy easy.'
TABLE 2

Distribution of demographic and socio-economic characteristics of study participants by their ART adherence pattern

\begin{tabular}{|c|c|c|c|}
\hline CHARACTERISTICS & $\begin{array}{l}\text { GOOD } \\
\text { ADHERENCE }\end{array}$ & $\begin{array}{l}\text { POOR } \\
\text { ADHERENCE }\end{array}$ & $\begin{array}{l}\text { SIGNIFI- } \\
\text { CANCE }\end{array}$ \\
\hline $\begin{array}{l}\text { EDUCATION STATUS } \\
\text { No formal education } \\
\text { Formal education }\end{array}$ & $\begin{array}{r}6(13.3) \\
47(62.7)\end{array}$ & $\begin{array}{l}39(86.7) \\
28(37.3)\end{array}$ & $\begin{array}{l}x^{2}=27.758 \\
d f=1 \\
p=0.000\end{array}$ \\
\hline $\begin{array}{l}\text { TOTAL MONTHLY INCOME } \\
\text { Less than N5 } 000 \\
\text { N5 } 000 \text { and more }\end{array}$ & $\begin{array}{l}22(28.2) \\
31(73.8)\end{array}$ & $\begin{array}{l}56(71.8) \\
11(26.2)\end{array}$ & $\begin{array}{l}X^{2}=23.024 \\
d f=1 \\
p=0.000\end{array}$ \\
\hline $\begin{array}{l}\text { SOURCES OF ARV DRUGS } \\
\text { Ife } \\
\text { llesa }\end{array}$ & $\begin{array}{c}7(14.0 \%) \\
46(65.7 \%)\end{array}$ & $\begin{array}{l}43(86.0 \%) \\
24(34.3 \%)\end{array}$ & $\begin{array}{l}X^{2}=31.631 \\
\mathrm{df}=1 \\
\mathrm{p}=\mathbf{0 . 0 0 0}\end{array}$ \\
\hline $\begin{array}{l}\text { AFFORDABILITY OF ARV DRUGS } \\
\text { Can easily afford costs } \\
\text { Find cost of ARV drugs expensive }\end{array}$ & $\begin{array}{l}20(71.4 \%) \\
33(35.9 \%)\end{array}$ & $\begin{array}{r}8(28.6 \%) \\
59(64.1 \%)\end{array}$ & $\begin{array}{l}X^{2}=11.007 \\
d f=1 \\
p=0.001\end{array}$ \\
\hline $\begin{array}{l}\text { SUPPORT GROUP ATTENDANCE } \\
\text { Yes } \\
\text { No }\end{array}$ & $\begin{array}{l}37(56.9 \%) \\
16(29.1 \%)\end{array}$ & $\begin{array}{l}28(43.1 \%) \\
39(70.9 \%)\end{array}$ & $\begin{array}{l}X^{2}=9.358 \\
\mathrm{df}=1 \\
\mathrm{p}=\mathbf{0 . 0 0 2}\end{array}$ \\
\hline $\begin{array}{l}\text { OCCUPATION } \\
\text { Currently employed } \\
\text { Not currently employed }\end{array}$ & $\begin{array}{l}33(37.1) \\
20(64.5)\end{array}$ & $\begin{array}{l}56(62.9) \\
11(35.5)\end{array}$ & $\begin{array}{l}X^{2}=7.019 \\
\mathrm{df}=1 \\
p=\mathbf{0 . 0 0 8}\end{array}$ \\
\hline $\begin{array}{l}\text { PERCEPTIONS OF ARV DOSAGE } \\
\text { REGIMEN } \\
\text { Find frequency cumbersome } \\
\text { Do not find it cumbersome }\end{array}$ & $\begin{array}{r}2(20.0 \%) \\
45(40.9 \%)\end{array}$ & $\begin{array}{r}8(80.0 \%) \\
65(59.1 \%)\end{array}$ & $\begin{array}{l}X^{2}=5.680 \\
\mathrm{df}=1 \\
\mathrm{p}=\mathbf{0 . 0 1 7}\end{array}$ \\
\hline $\begin{array}{l}\text { AGE GROUP } \\
\text { Less than } 45 \text { years } \\
45 \text { years and older }\end{array}$ & $\begin{array}{l}39(45.9) \\
14(40.0)\end{array}$ & $\begin{array}{l}46(54.1) \\
21(60.0)\end{array}$ & $\begin{array}{l}X^{2}=0.348 \\
\mathrm{df}=1 \\
\mathrm{p}=0.555\end{array}$ \\
\hline $\begin{array}{l}\text { SEX } \\
\text { Female } \\
\text { Male }\end{array}$ & $\begin{array}{l}33(41.8 \%) \\
20(48.8 \%)\end{array}$ & $\begin{array}{l}46(58.2 \%) \\
21(51.2 \%)\end{array}$ & $\begin{array}{l}X^{2}=0.538 \\
\mathrm{df}=1 \\
p=0.463\end{array}$ \\
\hline $\begin{array}{l}\text { MARITAL STATUS } \\
\text { Currently married } \\
\text { Not currently married }\end{array}$ & $\begin{array}{l}29(46.0) \\
24(42.1)\end{array}$ & $\begin{array}{l}34(54.0) \\
33(57.9)\end{array}$ & $\begin{array}{l}X^{2}=0.187 \\
d f=1 \\
p=0.665\end{array}$ \\
\hline $\begin{array}{l}\text { PERCEPTIONS OF ATTITUDES } \\
\text { OF SERVICE PROVIDERS } \\
\text { It is a barrier to adherence } \\
\text { It is not a barrier to adherence }\end{array}$ & $\begin{array}{r}44(45.8 \%) \\
9(37.5 \%)\end{array}$ & $\begin{array}{l}52(54.2 \%) \\
15(62.5 \%)\end{array}$ & $\begin{array}{l}X^{2}=0.541 \\
\mathrm{df}=1 \\
\mathrm{p}=0.462\end{array}$ \\
\hline $\begin{array}{l}\text { PERCEPTIONS OF SIDE } \\
\text { EFFECTS OF ARV DRUGS } \\
\text { It is a barrier to adherence } \\
\text { It is not a barrier to adherence }\end{array}$ & $\begin{array}{l}5(27.8 \%) \\
48(47.1 \%)\end{array}$ & $\begin{array}{l}13(72.2 \%) \\
54(52.9 \%)\end{array}$ & $\begin{array}{l}X^{2}=2.307 \\
\mathrm{df}=1 \\
\mathrm{p}=0.129\end{array}$ \\
\hline
\end{tabular}

TABLE 3

Logistic regression analyses of the significant correlates of adherence to ART among study participants

\begin{tabular}{|c|c|c|c|c|c|c|}
\hline & \multirow[t]{2}{*}{ B } & \multirow[t]{2}{*}{ S.E. } & \multirow[t]{2}{*}{ df } & \multirow[t]{2}{*}{ Sig. } & \multicolumn{2}{|c|}{$\begin{array}{l}95.0 \% \text { C.I. for } \\
\text { EXP(B) }\end{array}$} \\
\hline & & & & & LOWER & UPPER \\
\hline Sources of ARV drugs & 2.139 & 0.695 & 1 & 0.002 & 2.173 & 33.152 \\
\hline Educational attainment & 2.933 & 0.690 & 1 & 0.000 & 4.862 & 72.575 \\
\hline Total monthly income & 1.308 & 0.627 & 1 & 0.037 & 1.082 & 12.656 \\
\hline $\begin{array}{l}\text { Affordability of ARV } \\
\text { drugs }\end{array}$ & -0.507 & 0.690 & 1 & 0.463 & 0.156 & 2.332 \\
\hline $\begin{array}{l}\text { Support group } \\
\text { attendance }\end{array}$ & -0.798 & 0.572 & 1 & 0.163 & 0.147 & 1.381 \\
\hline Employment status & 1.182 & 0.683 & 1 & 0.084 & 0.855 & 12.435 \\
\hline Freq. of medication & -2.652 & 1.004 & 1 & 0.008 & 0.010 & 0.504 \\
\hline
\end{tabular}

Responses from the focus group discussion sessions provided further insight into the factors that influenced clients' adherence. A majority of participants in Ile-Ife complained about the cost of investigations before commencing ART, while those in Ilesa acknowledged that ARV drugs were free of charge, but that they found it difficult to get the transport fare to Lagos where they received the drugs. One of them said: 
"The major problem I have with ARV is the cost. Although government has made it free, we still need to obtain the drug from Lagos. The transport money then becomes a burden.'

Another participant disclosed that:

'It is not that the drug is very expensive, after all, it was subsidised before, and now [it is] almost free. The major problem is that many of us are not gainfully employed. Like me, I was sacked when my employer knew I was HIV positive. This lack of regular income makes getting the drug a serious problem.

Very few PLWHA complained about swallowing the drug. It was also reported that the smell of the drug as well as frequency of medication did not pose any serious barrier to adherence to ART. The support received by the PLWHA was also examined. Most of them remarked that they were neither supported financially nor morally by their close relatives. A lady from Ilesa said:

'My friends and relatives think I can inflict HIV on them. Some of them see me as a living corpse. I was thrown out of my husband's house after his death. I received no support, except from this place.'

\section{Another lady from Ile-Ife lamented:}

'My relations and friends left me alone. Even in my church the news of my HIV status called for a meeting because I was one of the church workers. I was asked to resign. They said that the news of my HIV status will negatively affect the congregation.'

A few participants said that the adverse effects of the drugs discouraged them from taking ARV medication. A female participant from Ilesa said:

'When I was having rashes, I reduced ARV intake, thinking it will reduce the rashes, even though I was advised not to stop or reduce it.'

\section{Another participant from Ife reported the following:}

'I was somehow discouraged from taking the drug, especially when I first started. I had poor appetite. When I forced myself to eat, I would vomit.'

On the premise that client-provider relationships may influence adherence, questions were asked about the attitude of care providers and how it influenced adherence to ART. The majority of the participants from the two sites described the attitude of providers as very pleasant and quite encouraging. The participants elaborated that counselling by these workers has helped tremendously in ensuring adherence to ART. When asked how adherence could be improved, the PLWHA suggested various ways, including the use of a mobile phone alarm or reminder tones, increasing access to ARV drugs by decentralising the treatment centres and addressing the issues of stigma in the society.

\section{DISCUSSION}

The socio-demographic profile of the participants showed that the majority $(70.8 \%)$ were in the age group of 15 to 44 years, with a female preponderance. This is consistent with findings of surveys that identified people of this age group as most vulnerable to HIV/AIDS because they belong to the sexually active, reproductive age group. ${ }^{23,24}$ The findings relating to the high proportion of female PLWHA in this study also support other findings that HIV infection is more common in women than men. Socio-cultural and economic factors that put women at a disadvantage are responsible for this difference. ${ }^{25}$

About half of the participants were currently married while significant proportions were either widowed or unmarried. This distribution of marital status becomes relevant, considering the fact that heterosexual transmission accounts for $80 \%$ of HIV infection in developing countries. ${ }^{24,25}$ A substantial proportion of the subjects were unemployed, while those who were employed were artisans in the low socio-economic class. This was clearly demonstrated during focus group discussions, when a lack of funds for investigations was given as a strong reason for poor adherence to ART. Membership of a support group was reported in a majority of subjects from Ilesa. The PLWHA enjoyed tremendous comradeship in these groups and regular attendance at the fortnightly meetings was associated with good adherence to ART.

The overall adherence level among the study population was $44 \%$. Although the majority of subjects who accessed ARV drugs from LIHOC, Ilesa, had good adherence, the converse was true for subjects who accessed ARV drugs from Ile-Ife. Nevertheless, the findings of this study suggest that the adherence rate among PLWHA to ART in the Ife-Ijesa zone of Osun State is comparable to those in most countries. In developed countries, the rates of patient-reported adherence range from $40 \%$ to $70 \% .{ }^{8}$ Also, the level of adherence observed in the present study is consistent with findings in Uganda, ${ }^{26}$ South Africa ${ }^{27}$ and Senegal. ${ }^{28}$

The low adherence rate from Ile-Ife may be explained by a number of factors. Firstly, subjects from Ile-Ife had to pay for certain investigations before they can benefit from the free ARV drugs, whereas the subjects from Ilesa only needed to provide transport fare to Lagos where the investigations were done free of charge and they commenced medication subsequently. Another factor that might have contributed to the relatively high adherence rate among participants from Ilesa is the nature and quality of support received from the care institution. Adherence and psychosocial counselling services were offered to PLWHA on ART in LIHOC, Ilesa, while such services were barely available in Ile-Ife at the time of this study. The moral and psychological support received from the group in Ilesa probably cushioned the negative effects of stigma and discrimination of PLWHA by some families and members of the community, and thereby improved adherence. Further studies employing an objective assessment of social support among PLWHA may confirm this conclusion.

Moreover, a significant positive association was obtained between sources of ART and adherence level. This factor remains a strong predictor of adherence to ART on multiple logistic regression analyses. This agrees with the findings of Sheri et al., ${ }^{20}$ who reported a higher adherence level in private sectors in Botswana than in public health facilities.

Education status had a significant association with adherence level in this study. Also, employment status and monthly income, which are directly dependent on education status, also showed significant association with adherence level. Perception of the cost as affordable or expensive was also significantly related to adherence level. These socio-demographic factors were reported by Nwokike ${ }^{21}$ to correlate well with good adherence to ART. He submitted that if cost is removed as a barrier, adherence is predicted to increase considerably. Our findings further revealed a significant association between frequency of ARV drug use and adherence level. This was stressed during focus group discussion during focus group discussions as responsible for missing some doses of ARV drugs. A simpler regimen of the medication was reported by other studies as promoting adherence to ART..$^{13,19}$

Other demographic factors such as age, gender and marital status did not have significant associations with adherence level. This is consistent with findings of other authors such as Glifford et al., ${ }^{29}$ Kleeberger et al., ${ }^{13}$ and Byakika-Tusiime et al. ${ }^{26}$

Similarly, experience of adverse effects was found not to be a significant correlate of adherence level in this study. This is contrary to the findings of Max and Sherer, association between frequency of ARV drug use and adherence level. This was stressed during focus group discussion as responsible for 
missing some doses of $A R V{ }^{30}$ who report that adverse drug reaction had a significant negative effect on adherence to ART. A lack of association in this study may be due to the fact that a significant proportion of PLWHA might have adjusted to the adverse effects of ARV drugs with time. The attitude of care providers also did not correlate with adherence to ART in this study. This negates the findings of other studies $21,31,32$ that established a positive influence of the attitude of care providers on adherence to ART. This discrepancy may be connected with the large sample size in those other studies, in sharp contrast with the relatively small sample size in the present study. Nevertheless, focus group discussion participants generally reported a favourable and encouraging attitude on the part of care givers in this study.

The use of self-report medication adherence to assess medication adherence may be a limitation of this study. Although efforts were made to limit recall of medication to the seven days before the interview, it is possible that subjects over- or underestimated their adherence to ART. This is further worsened by the inability to corroborate patient self-report of adherence with viral loads and $\mathrm{CD} 4$ responses because of financial and logistic constraints of frequent laboratory monitoring. However, the use of focus group discussions in this study revealed a number of behavioural factors that might not have been elicited by quantitative instruments.

In conclusion, adherence is an important predictor of viral suppression, reversal of progression to AIDS and death. The maximisation of treatment outcomes with expanding access to ART in resource-limited settings such as Nigeria will require a thorough understanding of the adherence barriers that are unique to resource-poor settings. This therefore implies that further studies are needed to objectively examine the impact of social support on the level of adherence to ART, especially in resource-constrained settings where other support systems are limited. Because the cost of accessing services was a demonstrable barrier to ART adherence, it is recommended that ART centres be decentralised into primary health care units that are closer to people's homes and places of work. The needed facilities and manpower should also be provided in order to make ART more accessible and affordable. Government should make both preliminary investigations for commencement of ART and ART free at all levels of care. This will improve access to ARV drugs and enhance adherence to the medication. There is also an urgent need for an effective and sustainable information, education and communication strategy nationwide to address the problem of HIV stigma and discrimination, which is a proven barrier to care and adherence to therapy. Government and non-governmental agencies are particularly enjoined to make this a priority for lasting HIV / AIDS prevention and control in the country.

\section{REFERENCES}

1. Hogg RS, Heath KV, Yip B, et al. Improved survival among HIV-infected individuals following initiation of antiretroviral therapy. JAMA. 1998;279:450-454.

2. Mocroft A, Vella S, Benfeld TL, et al. Changing patterns of mortality across Europe in patients infected with HIV. Lancet. 98:3521:1725-1730.

3. Paterson DL, Swindells S, Mohr J, et al. Adherence to protease inhibitor and outcomes in patients with HIV infection. Ann Int Med. 2000;133(1):21-30.

4. PerelsonAS,NeumannAU\&MarkowitzM.HIV-1 dynamics in viro, viron clearance rate, infected cell life span, and viral generation time. Science. 1996;271(5255):1582-1586.

5. Lucas GM, Chaisson RE \& Moore RD. Highly active antiretroviral therapy in a large urban clinic: Risk factors for virologic failure and adverse drug reactions. Ann Intern Med. 1999:131:81-87.

6. Wainberg MA \& Friedland G. Public health implications of antiretroviral therapy and HIV drug resistance. JAMA. 1998;279:1977-1983.
7. Deeks SG, Beatty G, Cohen PT, Grant R, Volberding P. Viral load and CD4+ T-cell changes in patients failing potential protease inhibitor therapy. Paper presented at: Fifth Conference on Retroviruses and Opportunistic Infections; 1998 Feb 1-5; Chicago, USA.

8. Haubrich RH, Little SJ \& Currier JS. The value of patientreported adherence to antiretroviral therapy in predicting virologic and immunologic response. California Collaborative Treatment Group. AIDS. 1999;13:1099-1107.

9. Chesney M. New antiviral therapies: Adherence challenges and strategies. Clinical Care Options for HIV Treatment Issues [homepage on the Internet]. No date [cited $2007 \mathrm{Jan}$ 27]. Available from: www.healthcg.com/hiv/treatment/ icacac97/adherence/chesney.html

10. Gordillo V, Del Amo J, Soriano V, Gonzalez-Lahoz J. Sociodemographic and psychological variables influencing adherence to antiretroviral therapy. AIDS. 1999;13:17631769.

11. Chesney MA, Ickovics JR, Chambers DB, et al. Selfreported adherence to antiretroviral medication among participants in HIV clinical trials: The AACTG Adherence Instruments. AIDS Care. 2000;12:255-266.

12. Singh N, Squier C, Sivek C, Wagener M, Nguyen MH \& $\mathrm{Yu}$ VL. Determinants of compliance with antiretroviral therapy in patients with human immunodeficiency virus: Prospective assessment with implications for enhancing compliance. AIDS Care. 1996;8:261-269.

13. Kleeberger CA, Phair JP, Strathdes SA. Determinants of heterogeneous adherence to HIV antiretroviral therapies in the multi-center AIDS cohort study. Journal of Acquired Immune Deficiency Syndrome. 2001;26:86-92.

14. Nemes MIB, Souza MM, Souza A, Grangeiro A, Souza RS \& Lopes JF. Prevalência da aderência e fatores associados. In: Ministério da Saúde do Brasil, Coordenação Nacional de DST AIDS. Aderência ao Tratamento por Anti-Retrovirais em Serviços Públicos no Estado de São Paulo. Ministério da Saúde do Brasil, Brasília, DF, Brazil 2000;65-101.

15. Kalichman SC, Ramachandran B, Catz S. Adherence to combination antiretroviral therapies in HIV patients of low health literacy. J Gen Intern Med. 1999;14:267-273.

16. Catz SL, Kelly JA, Bogart LM, Benotsch EG, McAuliffe TL. Patterns, correlates, and barriers to medication adherence among persons prescribed new treatments for HIV disease. Health Psychol. 2000;19:124-133.

17. Tuldrà $\mathrm{A}$, Fumaz $\mathrm{CR}$, Ferrer $\mathrm{MJ}$, et al. Prospective randomized two-arm controlled study to determine the efficacy of specific intervention to improve long-term adherence to highly active antiretroviral therapy. Journal of Acquired Immune Deficiency Syndrome. 2000;25:221228.

18. Samet JH, Libman H, Steger KA, et al. Compliance with Zidovudine therapy in patients infected with human immunodeficiency virus type 1: A cross-sectional study in a municipal hospital clinic. Am J Med. 1992;92:495-502.

19. Ickovics JR, Meisler AW. Adherence in AIDS clinical trials: A framework for clinical research and clinical care. J Clin Epidemiol. 1997;50:385-391.

20. Sheri W, William W, David B. Barriers to antiretroviral adherence for patients living with HIV infection and AIDS in Botswana. AIDS. 2003;34(3):73-77.

21. Nwokike JI. Baseline data and predictors of adherence to antiretroviral therapy in Maun General Hospital (MGH) Botswana. Paper presented at: Second International AIDS Society Conference on HIV Pathogenesis and Treatment; 2003 July 13-16; Paris, France.

22. NACA. HIV Sentinel Survey Surveillance among high risk population in Nigeria, Abuja 2003.

23. UNAIDS, World Health Organization and UNICEF. Epidemiological fact sheets on HIV/AIDS and sexually transmitted infections in Nigeria [homepage on the Internet]. 2004. Available from: http://data.unaids.org/ Publications/Fact-Sheets01/nigeria_en.pdf

24. Federal Ministry of Health. Department of Public Health, National AIDS/STD Control Programme: A technical report on the 2001 national HIV/syphilis sentinel survey 
among pregnant women attending antenatal clinics in Nigeria. Abuja: Nigerian Government; 2002.

25. Federal Ministry of Health. HIV/AIDS: What it is meant for Nigeria- Background, projection, impact, intervention and policy. Abuja: Nigerian Government; 2002.

26. Byakike-Tusiime J, Oyugi JH, Tumwikire WA. Adherence to HIV antiretroviral therapy in HIV + Ugandan patients purchasing therapy. Int J STD AIDS. 2005;16:38-41.

27. Orrell C, Wood R. Initial data on antiretroviral adherence in Cape Town, South Africa. Paper presented at: 1st IAS Conference on HIV Pathogenesis and Treatment; 2001 July 8-11; Buenos Aires, Argentina.

28. Laurent C, Diakhate N, Gueye NF. The Senegalese government'shighly activeantiretroviral therapyinitiative: An 18-month follow-up study. AIDS. 2002;16:1363-1370.
29. Glifford A, Borman J, Shively M, Wright B, Richman D, Brozzette S. Predictors of self-reported adherence and plasma HIV concentration in patients on multidrug antiretroviral regime. AIDS. 2000;23:236-295.

30. Max B, Sherer R. Management of the adverse effects of ARV therapy and medication adherence. Clin Infect Dis. 2000;30:596-600.

31. Pacific Alliance on Antiretroviral Adherence, Counselling, and Therapy (PAAACT). Living with HIV/Living with HAART: Managing antiretroviral side-effects. AIDS Research Institute. San Francisco: UCSF; 1999.

32. Nooring S, Dubler NN, Birkhead G, Agins B. A new paradigm for HIV care: Ethical and clinical considerations. Am J Public Health. 2001;91:690-694. 